\title{
Effects of Dietary Fiber Extracts from Brewer's Spent Grain on Quality Characteristics of Chicken Patties Cooked in Convective Oven
}

\author{
Hyun-Wook Kim, Ko-Eun Hwang, Dong-Heon Song, Soo-Yeon Lee, Min-Sung Choi, Yun-Bin Lim, \\ Ji-Hun Choi, Yun-Sang Choi ${ }^{1}$, Hack-Youn Kim², and Cheon-Jei Kim* \\ Department of Food Science and Biotechnology of Animal Resources, Konkuk University, Seoul 143-701, Korea \\ ${ }^{1}$ Food and Biological Resources Examination Division, Korean Intellectual Property Office, Daejeon 302-701, Korea \\ ${ }^{2}$ Department of Animal Resources Science, Kongju National University, Yesan 340-702, Korea
}

\begin{abstract}
Brewer's spent grain (BSG) is a by-product of beer manufacturing. This study was conducted to evaluate the effect of dietary fiber extracts from brewer's spent grain on quality characteristics of chicken patties. The total fiber content of BSG dietary fiber extracts after extraction increased from $58.11 \%$ to $68.57 \%$, and the extracted dietary fiber extracts were added to chicken patties at $0,1,2,3$, and $4 \%$, respectively. The effects of the BSG dietary fiber extracts on $\mathrm{pH}$, color, cooking loss, reduction in patty diameter, salt-soluble protein solubility, texture, and sensory characteristics of chicken patties were evaluated. The addition of BSG dietary fiber extracts decreased $\mathrm{pH}$ and lightness values, and increased redness and yellowness. Chicken patties formulated with 3-4\% BSG dietary fiber extracts had the lowest cooking loss among all treatments $(p<0.05)$. The diameter of chicken patties was not affected by the addition of BSG dietary fiber extracts. Additionally, no significant difference was observed in salt-soluble protein solubility after adding 3\% BSG dietary fiber extracts compared to that in the control. Textural and sensory properties were different among the chicken patties, and the 3\% BSG dietary fiber-added chicken patty had the highest acceptability. Our results indicate that $3 \%$ BSG dietary fiber extract can be used as a good source of dietary fiber for improving the quality characteristics of chicken patties.
\end{abstract}

Key words: brewer's spent grain, dietary fiber, chicken patty

\section{Introduction}

Dietary fiber has received much attention from the food industry as a functional ingredient to improve food quality and to provide physiological benefits such as regulation of cholesterol and prevention of diabetes and intestinal cancer (Özvural et al., 2009). In particular, dietary fiber is extensively used to improve textural and sensory properties in many sectors of the meat industry (Waszkowiak and Szymanadera-Buszka, 2008). Applications of dietary fiber extracted from cereals, fruits, and vegetables, including apple, lemon, oat bran, peach, rye bran, and wheat (Fernández-Ginés et al., 2004; García et al., 2002; Y1lmaz, 2004), have been extensively examined, considering the characteristics and types of applied meat products. Applying dietary fiber in by-products derived

\footnotetext{
*Corresponding author: Cheon-Jei Kim, Department of Food Science and Biotechnology of Animal Resources, Konkuk University, Seoul 143-701, Korea. Tel: 82-2-450-3684, Fax: 82-2-4446695, E-mail: kimcj@konkuk.ac.kr
}

from the agri-food industry has been examined in several foods. Improved quality of low-fat beef burgers was observed by adding $1-2 \%$ hazelnut pellicle (Turhan et al., 2005). Choi et al. (2011) added extracted rice bran fiber, which is generated during rice polishing, to pork salt-soluble proteins. The results indicated that adding rice bran fiber increased apparent viscosity. Additionally, Choi et al. (2013) reported that makgeolli lees fiber, which is a by-product of makgeolli (Korean traditional alcoholic drink), improves the textural and sensory properties of chicken emulsion sausage.

Barley is a one of the most important cereals in the world and has been used as a main ingredient to make various foods. In particular, malt, which is generated from barely grain, is important to produce alcoholic drinks, including beer and whisky (Jadhav et al., 1998). Various by-products derived from main ingredients such as spent grains, spent hops, and surplus yeast are generated during beef manufacturing (Aliyu and Bala, 2011). Approximately $85 \%$ of the total brewing by-product is brewer's spent grain (BSG), which has been recognized as a func- 
tional material, and is rich in dietary fiber and low cost by-products (Gupta et al., 2010; Musatto et al., 2006; Robertson et al., 2010). Mussatto et al. (2008) also reported that BSG contains cellulose (16.8\%), hemicellulose (28.4\%), and lignin (27.8\%). Thus, BSG seems to be a good dietary fiber source to enhance meat product quality and to develop functional and low-fat meat products. Özvural et al. (2009) prepared frankfurters using BSG and concluded that BSG is a high source of dietary fiber to produce low fat meat products. However, information on BSG dietary fiber extracts remains limited, and studies are needed to develop BSG dietary fiber extracting processes and to evaluate the effect of high-fiber BSG on meat product quality characteristics.

Therefore, the objectives of this study were to investigate the effect of incorporating a BSG dietary fiber extract into chicken breasts at five different levels on physicochemical, textural, and sensory properties of chicken patties.

\section{Materials and Methods}

\section{Preparation of dietary fiber extracts from brewer's spent grain (BSG)}

Dietary fiber was extracted using the modified method of Choi et al. (2011) based on the AOAC enzymaticgravimetric method (2007). BSG was obtained from a commercial brewery (Hitejinro Co., Ltd., Korea). BSG was washed three times with five volume of distilled water to remove alcoholic components and foreign bodies. To prevent rancidity in BSG, the residues were defatted with five volume of hexane (n-hexane 95\%) on a shaker (BS-11, Lab. Companion, Korea) for $24 \mathrm{~h}$. The defatted BSG was gelatinized with $0.6 \%$ termamyl (heat stable alpha-amylase) in a $95^{\circ} \mathrm{C}$ water bath for $1 \mathrm{~h}$ to remove starch. After filtration, the residues were washed three times with four volumes of heated distilled water $\left(100^{\circ} \mathrm{C}\right)$ and cooled to equilibrate to room temperature $\left(20^{\circ} \mathrm{C}\right)$. And then, the residues were washed with $99.9 \%$ ethanol (preheated to $60^{\circ} \mathrm{C}$ ) followed by filtration. The residues were dried in a $55^{\circ} \mathrm{C}$ hot air dryer (Enex-Co-600, Enexs, Korea) for $24 \mathrm{~h}$. The dried residues were pulverized using a milling machine (DK504, Sejungtech, Korea), and the powder were passed through the 270 mesh testing sieves (Chung Gey Industrial Mfg. Co., Korea). A yield of powder was more than $95 \%$. The proximate composition of BSG dietary fiber extracts was determined using AOAC guidelines (2007), and the results are shown in Table 1.
Table 1. Proximate composition (\%) of brewer's spent grain (BSG) dietary fiber extracts

\begin{tabular}{lcrc}
\hline \hline $\begin{array}{c}\text { Traits } \\
\text { (Dry basis) }\end{array}$ & \multicolumn{1}{c}{$\begin{array}{c}\text { Before } \\
\text { extracting }\end{array}$} & \multicolumn{1}{c}{$\begin{array}{c}\text { After } \\
\text { extracting }\end{array}$} & $\begin{array}{c}\text { Significance } \\
\text { (t-test) }^{2}\end{array}$ \\
\hline Moisture & $4.28 \pm 0.53^{3)}$ & $4.40 \pm 0.40$ & NS \\
Crude protein & $19.60 \pm 0.15$ & $13.72 \pm 0.34$ & $* * *$ \\
Crude fat & $13.37 \pm 0.45$ & $9.53 \pm 0.38$ & $* * *$ \\
Crude ash & $3.13 \pm 0.08$ & $2.97 \pm 0.06$ & $* *$ \\
Total dietary fiber & $58.11 \pm 0.07$ & $68.57 \pm 0.29$ & $* * *$ \\
\hline
\end{tabular}

${ }^{1)}$ The extracting condition was described in materials and methods.

${ }^{2)} \mathrm{NS} p>0.05,{ }^{*} p<0.05,{ }^{* *} p<0.01,{ }^{* * *} p<0.001$

${ }^{3)}$ All values are mean $\pm \mathrm{SD}(n=3)$.

\section{Preparation of chicken patties}

Chicken breast muscles (M. Pectoralis major) in fresh broilers (Arbor Acre strain, $5 \mathrm{wk}$ of age, approximately 1.5-2.0 kg live weight) and pork back fat were obtained from a local market. Visible connective tissue and excessive fat were removed from the fresh chicken breast muscles. The chicken breast and pork back fat were initially ground using a meat grinder (PM-70, Mainca, Spain) equipped with $8 \mathrm{~mm}$ plate. The ground chicken breast and pork back fat were packaged with Nylon/PE film, and used on the day.

All chicken patties were composed by $60 \%$ chicken breast, $20 \%$ pork back fat, $20 \%$ ice, and $1.5 \% \mathrm{NaCl}$. And each sample batch consisted of five chicken patties differing in composition with respect to addition of BSG dietary fiber extracts levels $(0,1,2,3$, and $4 \%)$. The mixture from each batch was mixed using a mixer (RM-90, Mainca, Spain) for $10 \mathrm{~min}$. After the batches were held at $4^{\circ} \mathrm{C}$ for $1 \mathrm{~h}$ (Troutt and Dale, 1990), the batches were processed into $100 \pm 1 \mathrm{~g}$ patties with $100 \mathrm{~mm}$ in diameter and $15 \mathrm{~mm}$ in thickness using patty presses (Small ground press, Spikomat Ltd., UK). All chicken patties were then placed in Nylon/PE film, and stored $-20^{\circ} \mathrm{C}$ to maintain shape of the chicken patties. After $24 \mathrm{~h}$ of manufacturing, the chicken patties were used in analysis.

\section{Cooking method of chicken patties}

The cooking final temperature was heated until the core temperatures of chicken patties reached to $75^{\circ} \mathrm{C}$. As a commonly used method for cooking of poultry products (Murphy et al., 2001), the samples were heated using convective oven (OES 6.06, Convotherm, Germany) at $150^{\circ} \mathrm{C}$ for $7 \mathrm{~min}$. Each patty was placed in the center of a shelf in oven, until the targeted core temperature was reached. The core temperature of patty was monitored with a digital thermometer (Tes-1305, Tes Electrical Co., 
Taiwan) equipped with a data logger (RS-232, Tes Electrical Co., Taiwan) by inserting a iron constantan thermocouple.

\section{pH measurements}

The $\mathrm{pH}$ values of raw and cooked chicken patties were determined with a $\mathrm{pH}$ meter (Model 340, Mettler-Toledo $\mathrm{GmbH}$, Switzerland). The $\mathrm{pH}$ values of samples were measured by blending a $5 \mathrm{~g}$ sample with $50 \mathrm{~mL}$ distilled water for $60 \mathrm{~s}$ in a homogenizer at 8,000 rpm (Ultra-Turrax SK15, Janke \& Kunkel, Germany).

\section{Instrumental color evaluation}

Instrumental color were determined using a colorimeter (Minolta Chroma meter CR-210, Japan; illuminate C, calibrated with a white plate, $\mathrm{CIE} \mathrm{L}^{*}=+97.83, \mathrm{CIE} \mathrm{a}^{*}=-0.43$, $\mathrm{CIE} \mathrm{b}^{*}=+1.98$ ). Five measurements for five locations on surface of raw and cooked chicken patties were taken. CIE L* (lightness), CIE a* (redness), and CIE $b^{*}$ (yellowness) values were recorded.

\section{Cooking loss}

As mentioned above, all chicken patties were cooked using convective oven (OES 6.06, Convotherm, Germany) at $150^{\circ} \mathrm{C}$ for 7 min until the targeted core temperature reached $75^{\circ} \mathrm{C}$. Percentage cooking loss was determined by calculating a percent reduction in weight, on an initial weight basis as follows.

\section{Cooking loss (\%)}

$=[($ weight of raw sample $(\mathrm{g})-$ weight of cooked sample $(\mathrm{g})) /$ weight of raw sample $(\mathrm{g})] \times 100$

\section{Reduction in diameter}

To measure the change in shape of chicken patties due to cooking, the reduction in diameter was determined by method of Choi et al. (2012). Firstly, two points in chicken patties were marked before cooking. After cooking, the diameter of the cooked patties was recorded using vernier calipers (530-122, Mitutoyo, Japan). The reduction in diameter was determined by calculating the length differences before and after cooking, and all determinations were performed in triplicate.

\section{Salt soluble protein solubility}

The solubility of the salt soluble (myofibrillar) protein was determined following the modification of procedures described by Saffle and Galbreath (1964). A 5 g sample

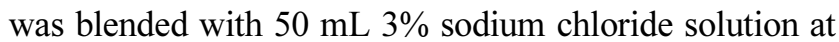

14,000 rpm for 2 min using homogenizer (AM-7, Nihonseiki Kaisha, Japan). The mixture was centrifuged at $1,100 \mathrm{~g}$ for $15 \mathrm{~min}$. The protein concentration of supernatant was determined by using the Biuret method (Gornall et al., 1949), with bovine serum albumin as a standard (Sigma Chemical Co., USA).

\section{Texture profile analysis (TPA)}

Texture profile analysis (TPA) was performed in triplicate on each sample at room temperature with a texture analyzer (TA-XT2i, Stable Micro Systems Ltd., England). The cooked chicken patties sized approximately 5.0×5.0 $\times 1.5 \mathrm{~cm}$ were cut from the central portion of each meat patty. Prior to analysis, samples were allowed to equilibrate to room temperature $\left(20^{\circ} \mathrm{C}, 3 \mathrm{~h}\right)$. The conditions of texture analysis were as follows: pre-test speed $2.0 \mathrm{~mm} / \mathrm{s}$, post-test speed $5.0 \mathrm{~mm} / \mathrm{s}$, maximum load $2 \mathrm{~kg}$, head speed $2.0 \mathrm{~mm} / \mathrm{s}$, distance $8.0 \mathrm{~mm}$, force $5 \mathrm{~g}$ (Choi et al., 2012). The calculation of texture profile analysis values was obtained by graphing a curve using force and time plots. Values for hardness $(\mathrm{kg})$, springiness, cohesiveness, gumminess $(\mathrm{kg})$, and chewiness $(\mathrm{kg})$ were determined as described by Bourne (1978).

\section{Sensory evaluation}

The cooked chicken patties were evaluated for color, flavor, off-flavor, tenderness, juiciness, and overall acceptance. The cooked samples as previously described were cooled to the room temperature at $25^{\circ} \mathrm{C}$ and cut and served to the panelists in random order. The sensory evaluations were performed by the panelists under fluorescence lighting. Panelists were instructed to cleanse their palates between samples using warm water. The color $(1=$ extremely undesirable, $10=$ extremely desirable), flavor (1=extremely undesirable, $10=$ extremely desirable), off-flavor ( $1=$ strong off-flavor, $10=$ weak off-flavor), tenderness $(1=$ extremely tough, $10=$ extremely tender), juiciness ( $1=$ extremely dry, $10=$ extremely juicy), and overall acceptance (1=extremely undesirable, $10=$ extremely desirable) of the cooked chicken patties were evaluated using a 10-point descriptive scale. The panel consisted of 12 members from the Department of Food Sciences and Biotechnology of Animal Resources at Konkuk University in Korea.

\section{Statistical analysis}

All tests were done at least three times for each experimental condition and mean values were reported. The obtained results of proximate composition of BSG dietary fiber extracts were statistically processed, and signifi- 
cance of difference between means (t-test) was determined. Among chicken patties treatments, an analysis of variance were also performed on all the variables measured using the general linear model (GLM) procedure of the SAS statistical package (SAS, 2008). Duncan's multiple range test $(p<0.05)$ was used to determine differences between treatment means.

\section{Results and Discussion}

\section{pH value and color}

The effects of the brewer's spent grain (BSG) dietary fiber extracts on $\mathrm{pH}$ and color of uncooked and cooked chicken patties are shown in Table 2. The pH of uncooked chicken patties decreased with increasing BSG dietary fiber extract level, and a significant difference in $\mathrm{pH}$ was observed by adding BSG dietary fiber extract $\geq 3 \%$ $(p<0.05)$. The $\mathrm{pH}$ of the BSG dietary fiber extract was 5.33 (data not shown); a lower $\mathrm{pH}$ value compared to that of chicken breast (5.82) lead to a decrease in the $\mathrm{pH}$ value of the chicken patties. Additionally, the $\mathrm{pH}$ of cooked chicken patties varied between 6.31 and 6.41 , and the results among treatments showed a similar tendency compared to those of uncooked chicken patties. Özvural et al. (2009) reported similar $\mathrm{pH}$ values (6.26-6.36) for frankfurters made with BSG $(0,1,3$, and $5 \%)$.

The color parameters of the BSG-added chicken patties were significantly different $(p<0.05)$. The increase in BSG dietary fiber extracts levels contributed to a decline in the CIE L ${ }^{*}$ value (lightness) of uncooked and cooked chicken patties, and the T4 treatment (4\% BSG dietary fiber extracts) resulted in the lowest lightness values in both raw and cooked chicken patties $(p<0.05)$. Raw and cooked chicken patty redness, as measured by the CIE a ${ }^{*}$ value, increased with an increase in BSG dietary fiber extracts levels. The highest redness values were observed after adding the BSG dietary fiber extract at $\geq 3 \%(p<0.05)$. All CIE $b^{*}$ values (yellowness) were significantly higher $(p<0.05)$ in the BSG dietary fiber treatments than those in the controls. Addition of BSG dietary fiber extracts lead to an increase in yellowness of the chicken patties when compared with that of the control, indicating that adding BSG dietary fiber resulted in a yellow or brownish-colored product. Adding dietary fiber extracts from cereal by-products, including oat bran (Hughes et al., 1997; Yllmaz and Dağlığlu, 2003), rice bran (Choi et al., 2011), and rye bran (Yllmaz, 2004), results in increased yellowness of meat products. Additionally, Yılmaz and Dağlıoğlu (2003) noted that the increased yellowness results from the carotenoid pigments in oat bran.

\section{Cooking loss, reduction in diameter, and salt solu- ble protein solubility}

Cooking loss is affected by various external and internal factors such as additives, cooking conditions, formulation, and water contents (Choi et al., 2009). In particular, adding dietary fiber improves cooking loss of a meat product due to water holding and fat absorption capacities (Thebaudin et al., 1997). The effect of the BSG dietary fiber extract on cooking loss of chicken patties is presented in Fig. 1. Cooking loss was significantly lower $(p<0.05)$ in chicken patties containing the BSG dietary fiber extract than that in the control. Chicken patties formulated with the $4 \%$ BSG dietary fiber extract (T4) was the lowest among all treatments; but, no significant difference was observed between T3 and T4. A similar result was reported by Özvural et al. (2009), who found that water holding capacity is associated with total dietary

Table 2. Effects of dietary fiber extracts from brewer's spent grain (BSG) on pH value and instrumental color of chicken patties

\begin{tabular}{|c|c|c|c|c|c|c|}
\hline \multirow{2}{*}{ Type } & \multirow{2}{*}{ Traits } & \multirow{2}{*}{ Con } & \multicolumn{4}{|c|}{ (Treatments ${ }^{1)}$} \\
\hline & & & $\mathrm{T} 1$ & $\mathrm{~T} 2$ & T3 & $\mathrm{T} 4$ \\
\hline \multirow{4}{*}{ Uncooked } & $\mathrm{pH}$ & $6.27 \pm 0.05^{2) a}$ & $6.25 \pm 0.03^{\mathrm{a}}$ & $6.25 \pm 0.03^{\mathrm{a}}$ & $6.21 \pm 0.06^{\mathrm{b}}$ & $6.17 \pm 0.05^{\mathrm{c}}$ \\
\hline & CIE L* & $64.00 \pm 1.91^{\mathrm{a}}$ & $62.00 \pm 2.99^{\mathrm{b}}$ & $57.90 \pm 1.70^{\mathrm{c}}$ & $56.59 \pm 1.40^{c}$ & $54.67 \pm 2.41^{\mathrm{d}}$ \\
\hline & CIE a ${ }^{*}$ & $2.62 \pm 0.27^{\mathrm{d}}$ & $3.83 \pm 0.54^{\mathrm{c}}$ & $4.30 \pm 0.45^{\mathrm{b}}$ & $4.88 \pm 0.44^{\mathrm{a}}$ & $4.98 \pm 0.26^{\mathrm{a}}$ \\
\hline & $\mathrm{CIE} \mathrm{b}^{*}$ & $16.40 \pm 1.74^{\mathrm{b}}$ & $18.77 \pm 1.66^{\mathrm{a}}$ & $18.89 \pm 1.28^{\mathrm{a}}$ & $19.52 \pm 1.07^{\mathrm{a}}$ & $19.54 \pm 0.67^{\mathrm{a}}$ \\
\hline \multirow{4}{*}{ Cooked } & $\mathrm{pH}$ & $6.41 \pm 0.03^{\mathrm{a}}$ & $6.39 \pm 0.03^{\mathrm{a}}$ & $6.39 \pm 0.02^{\mathrm{a}}$ & $6.32 \pm 0.06^{\mathrm{b}}$ & $6.31 \pm 0.06^{\mathrm{b}}$ \\
\hline & CIE L* & $68.45 \pm 3.85^{\mathrm{a}}$ & $62.10 \pm 2.91^{\mathrm{b}}$ & $57.34 \pm 3.52^{c}$ & $53.26 \pm 3.54^{\mathrm{d}}$ & $51.48 \pm 4.08^{\mathrm{d}}$ \\
\hline & CIE a ${ }^{*}$ & $2.51 \pm 0.74^{\mathrm{d}}$ & $3.51 \pm 1.04^{\mathrm{c}}$ & $4.64 \pm 0.88^{b}$ & $5.68 \pm 1.16^{\mathrm{a}}$ & $5.99 \pm 1.07^{\mathrm{a}}$ \\
\hline & $\mathrm{CIE} \mathrm{b}^{*}$ & $22.70 \pm 2.21^{\mathrm{b}}$ & $23.88 \pm 1.92^{\mathrm{ab}}$ & $24.36 \pm 1.66^{\mathrm{a}}$ & $25.12 \pm 1.54^{\mathrm{a}}$ & $25.53 \pm 1.71^{\mathrm{a}}$ \\
\hline
\end{tabular}

${ }^{1)}$ Treatments: Con, without BSG dietary fiber extracts; T1, with 1\% BSG dietary fiber extracts; T2, with 2\% BSG dietary fiber extracts; T3, with 3\% BSG dietary fiber extracts; T4, with 4\% BSG dietary fiber extracts.

${ }^{2)}$ All values are mean $\pm \mathrm{SD}(n=3)$.

${ }^{\mathrm{a}-\mathrm{d}}$ Means within a row with different letters are significantly different $(p<0.05)$. 


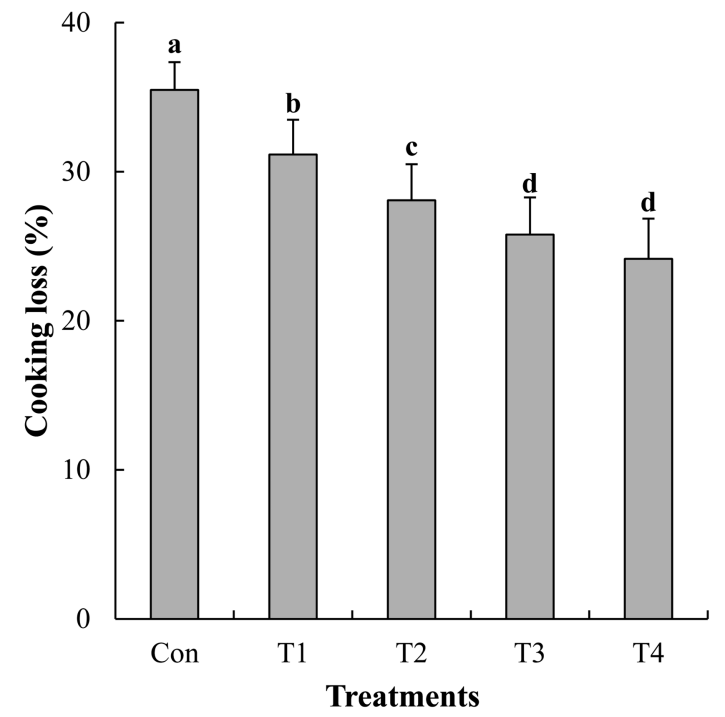

Fig. 1. Effect of dietary fiber extracts from brewer's spent grain (BSG) on cooking loss of chicken patties. Con, without BSG dietary fiber extracts; T1, with $1 \%$ BSG dietary fiber extracts; T2, with $2 \%$ BSG dietary fiber extracts; T3, with 3\% BSG dietary fiber extracts; T4, with $4 \%$ BSG dietary fiber extracts. All values are mean and SD of three replicates. a-d Means sharing different letters are significantly different $(p<0.05)$.

fiber value in frankfurters made with BSG. Similar cooking loss trends have been observed in many studies by adding different dietary fiber sources (Choi et al., 2011; Hughes et al., 1997).

The reduction in diameter of chicken patties varied with the level of the BSG dietary fiber extract added (Table 3). The reduction in chicken patty diameter in patties containing the BSG dietary fiber extracts was not significantly different $(p>0.05)$ from that in the control. However, a decreasing tendency was observed. A similar result was obtained by Troutt et al. (1992) for low-fat ground beef containing dietary fiber. Also, Piñero et al. (2008) reported no difference in the diameters of beef patties made with oat soluble fiber ( $\beta$-glucan), despite a weight loss difference after cooking.
Salt soluble proteins, which result in gel formation during thermal processing, are mainly associated with fat and water stabilization and meat particle binding in restructured meat products (McCord et al., 1998). Thus, salt soluble protein solubility is important for textural and sensory properties (Farouk et al., 2002). The effect of the BSG dietary fiber extracts on salt soluble protein solubility of the chicken patties is shown in Table 3. As a result, salt soluble protein solubility was affected by adding the BSG dietary fiber extracts. Increasing the concentration of the BSG dietary fiber extract led to a decrease in salt soluble protein solubility, and the solubility of chicken patties containing the $4 \%$ BSG dietary fiber extract (T4) was significantly lower $(p<0.05)$ than that in the other treatments. In contrast, Choi et al. (2011) noted that increased rice bran fiber levels contribute to increase solubility of sarcoplasmic, myofibrillar, and total proteins in heatinduced gels. In that study, the $\mathrm{pH}$ value of rice bran fiber was 7.07 , and adding rice bran fiber led to a higher $\mathrm{pH}$ value compared with that in treatments without rice bran fiber. However, the $\mathrm{pH}$ value decreased after adding the BSG dietary fiber extract in our study. Protein solubility depends on the $\mathrm{pH}$ value of the meat and improves at higher $\mathrm{pH}$ values (Feiner, 2006). Thus, this difference in protein solubility may be due to characteristics of the added dietary fiber sources, and our results suggest that adding 3\% BSG dietary fiber extract is the optimum amount regardless of salt soluble protein solubility.

\section{Texture profile analysis (TPA)}

The textural properties of chicken patties made with the BSG dietary fiber extracts are shown in Table 4. The hardness of the control patties was lower than that in chicken patties made with the different amounts of BSG dietary fiber extract, and increased BSG dietary fiber extract levels resulted in increased hardness of the chicken patties. Similarly, Yllmaz and Dağlığlu (2003) reported that increasing oat bran fiber increases the texture and firm-

Table 3. Comparison of reduction in diameter and salt soluble protein solubility of the chicken patties containing various brewer's spent grain (BSG) dietary fiber extracts

\begin{tabular}{lccccc}
\hline \hline \multirow{2}{*}{ Traits } & \multirow{2}{*}{ Con } & \multicolumn{4}{c}{ Treatments ${ }^{1)}$} \\
\cline { 3 - 6 } & & \multicolumn{1}{c}{ T1 } & T2 & T3 & T4 \\
\hline Reduction in diameter $(\%)$ & $18.65 \pm 1.31^{2)}$ & $18.62 \pm 1.96$ & $18.61 \pm 2.01$ & $18.13 \pm 2.02$ & $17.28 \pm 1.29$ \\
Salt soluble protein solubility $(\mathrm{mg} / \mathrm{g})$ & $9.98 \pm 0.71^{\mathrm{a}}$ & $9.62 \pm 0.82^{\mathrm{a}}$ & $9.55 \pm 0.68^{\mathrm{a}}$ & $9.43 \pm 0.34^{\mathrm{a}}$ & $8.79 \pm 0.83^{\mathrm{b}}$ \\
\hline
\end{tabular}

${ }^{1)}$ Treatments: Con, without BSG dietary fiber extracts; T1, with 1\% BSG dietary fiber extracts; T2, with 2\% BSG dietary fiber extracts; T3, with 3\% BSG dietary fiber extracts; T4, with 4\% BSG dietary fiber extracts.

${ }^{2)}$ All values are mean $\pm \mathrm{SD}(n=3)$.

${ }^{\mathrm{a}, \mathrm{b}}$ Means within a row with different letters are significantly different $(p<0.05)$. 
Table 4. Effects of dietary fiber extracts from brewer's spent grain (BSG) on textural properties of chicken patties

\begin{tabular}{lllclc}
\hline \hline \multirow{2}{*}{ Traits } & \multirow{2}{*}{ Con } & \multicolumn{4}{c}{ Treatments $^{1 \text { ) }}$} \\
\cline { 3 - 6 } & & \multicolumn{1}{c}{ T1 } & T2 & T3 \\
\hline Hardness (kg) & $8.06 \pm 0.58^{2) \mathrm{b}}$ & $8.43 \pm 0.59^{\mathrm{ab}}$ & $8.46 \pm 0.75^{\mathrm{ab}}$ & $8.75 \pm 0.66^{\mathrm{a}}$ & $8.82 \pm 0.76^{\mathrm{a}}$ \\
Springiness & $0.76 \pm 0.06$ & $0.77 \pm 0.06$ & $0.76 \pm 0.07$ & $0.75 \pm 0.05$ & $0.76 \pm 0.09$ \\
Cohesiveness & $0.44 \pm 0.02$ & $0.45 \pm 0.03$ & $0.45 \pm 0.04$ & $0.46 \pm 0.04$ & $0.47 \pm 0.04$ \\
Gumminess (kg) & $3.65 \pm 0.32^{\mathrm{b}}$ & $3.77 \pm 0.37^{\mathrm{ab}}$ & $3.79 \pm 0.43^{\mathrm{ab}}$ & $3.99 \pm 0.54^{\mathrm{a}}$ & $4.04 \pm 0.41^{\mathrm{a}}$ \\
Chewiness (kg) & $2.77 \pm 0.36$ & $2.90 \pm 0.35$ & $2.88 \pm 0.51$ & $3.00 \pm 0.42$ & $3.07 \pm 0.53$ \\
\hline
\end{tabular}

${ }^{1)}$ Treatments: Con, without BSG dietary fiber extracts; T1, with 1\% BSG dietary fiber extracts; T2, with 2\% BSG dietary fiber extracts; T3, with 3\% BSG dietary fiber extracts; T4, with 4\% BSG dietary fiber extracts.

${ }^{2)}$ All values are mean $\pm \mathrm{SD}(n=3)$.

${ }^{\mathrm{a}, \mathrm{b}}$ Means within a row with different letters are significantly different $(p<0.05)$.

ness of low-fat meat balls. Yllmaz (2005) noted that firmness of low fat meat balls with added wheat bran increases after adding more wheat bran. According to FernándezGinés et al. (2004), adding lemon albedo fiber increases hardness of bologna sausage compared to that in a control. Adding the BSG dietary fiber extracts did not affect the springiness of the chicken patties. Similar results were reported by Özvural et al. (2009) in BSG-supplemented frankfurters. Cohesiveness and chewiness tended to be higher in all chicken patties with the added BSG dietary fiber extracts compared to that in the control; but, the differences were not significant $(p>0.05)$. Gumminess was significantly $(p<0.05)$ higher in chicken patties containing the BSG dietary fiber extract than that in the control. The highest gumminess value was observed in the $4 \%$ BSG dietary fiber extracts treatment (T4).

\section{Sensory evaluation}

The sensory properties of chicken patties were significantly affected by the BGS dietary fiber extracts levels (Table 5). The color score was the highest for the T2 treatment, and all BSG dietary fiber extract treatments had higher color scores than that in the control. However, no significant differences $(p>0.05)$ were observed among the BSG dietary fiber extracts treatments. This result suggests that chicken patties were affected by adding the BSG dietary fiber extract, in which the color of the BSG dietary fiber was likely brown. Thus, the BSG dietary fiber extracts-treated chicken patties had a brownish color relative to that of the control and were the most appealing. The flavor score for the chicken patties with $4 \%$ added BSG dietary fiber extract (T4) was the lowest, and no significant difference $(p>0.05)$ was observed between the control and chicken patties containing 1, 2, or 3\% BSG dietary fiber extracts. The strong off-flavor score was recorded for the T4 treatment. Similarly, Özvural et al. (2009) noted that increasing BSG concentration results in a decreased flavor score. Our results suggest that the optimum level for the BSG dietary fiber extract was approximately $3 \%$ based on flavor, but further study is needed to investigate and remove off-flavor of the BSG dietary fiber extracts. Additionally, the tenderness and juiciness

Table 5. Effects of dietary fiber extracts from brewer's spent grain (BSG) on sensory properties of chicken patties

\begin{tabular}{lccccc}
\hline \hline \multirow{2}{*}{ Traits $^{2)}$} & \multirow{2}{*}{ Con } & \multicolumn{3}{c}{ Treatments $^{1)}$} \\
\cline { 3 - 6 } & & T1 & T2 & T3 & T4 \\
\hline Color & $7.53 \pm 0.72^{3) \mathrm{b}}$ & $8.00 \pm 0.87^{\mathrm{ab}}$ & $8.41 \pm 0.71^{\mathrm{a}}$ & $8.35 \pm 0.70^{\mathrm{a}}$ & $8.24 \pm 0.83^{\mathrm{a}}$ \\
Flavor & $8.24 \pm 0.56^{\mathrm{a}}$ & $8.12 \pm 0.78^{\mathrm{a}}$ & $8.24 \pm 0.83^{\mathrm{a}}$ & $8.18 \pm 0.73^{\mathrm{a}}$ & $7.47 \pm 0.62^{\mathrm{b}}$ \\
Off-flavor & $9.12 \pm 0.86^{\mathrm{a}}$ & $9.00 \pm 0.79^{\mathrm{a}}$ & $8.88 \pm 0.49^{\mathrm{ab}}$ & $8.73 \pm 0.51^{\mathrm{ab}}$ & $8.47 \pm 0.51^{\mathrm{b}}$ \\
Tenderness & $7.71 \pm 0.47^{\mathrm{b}}$ & $8.12 \pm 0.93^{\mathrm{ab}}$ & $8.47 \pm 1.01^{\mathrm{a}}$ & $8.35 \pm 0.79^{\mathrm{a}}$ & $8.41 \pm 0.94^{\mathrm{a}}$ \\
Juiciness & $7.71 \pm 0.69^{\mathrm{b}}$ & $7.94 \pm 0.66^{\mathrm{b}}$ & $8.41 \pm 0.62^{\mathrm{a}}$ & $8.71 \pm 0.59^{\mathrm{a}}$ & $8.53 \pm 0.62^{\mathrm{a}}$ \\
Overall acceptance & $7.94 \pm 0.66^{\mathrm{b}}$ & $8.24 \pm 0.90^{\mathrm{ab}}$ & $8.53 \pm 0.80^{\mathrm{a}}$ & $8.59 \pm 0.62^{\mathrm{a}}$ & $8.29 \pm 0.69^{\mathrm{ab}}$ \\
\hline
\end{tabular}

${ }^{1)}$ Treatments: Con, without BSG dietary fiber extracts; T1, with 1\% BSG dietary fiber extracts; T2, with 2\% BSG dietary fiber extracts; T3, with 3\% BSG dietary fiber extracts; T4, with 4\% BSG dietary fiber extracts.

${ }^{2)}$ Traits: color ( $1=$ extremely undesirable, $10=$ extremely desirable), flavor $(1=$ extremely undesirable, $10=$ extremely desirable), off-flavor ( $1=$ strong off-flavor, $10=$ weak off-flavor), tenderness ( $1=$ extremely tough, $10=$ extremely tender), juiciness $(1=$ extremely dry, $10=$ extremely juicy), and overall acceptance ( $1=$ extremely undesirable, $10=$ extremely desirable).

${ }^{3)}$ All values are mean $\pm \mathrm{SD}(n=12)$.

${ }^{\mathrm{a}, \mathrm{b}}$ Means within a row with different letters are significantly different $(p<0.05)$. 
scores of the chicken patties increased with added BSG dietary fiber extracts. Adding BSG dietary fiber extracts at $\geq 2 \%$ resulted in significantly higher $(p<0.05)$ tenderness and juiciness scores than that in the control. Overall, the chicken patties formulated with 3\% BSG dietary fiber extracts had the highest scores, whereas chicken patties without the BSG dietary fiber extract had the lowest score. In previous studies, adding dietary fiber to meat products resulted in enhanced sensory traits. Choi et al. (2012) reported that 1 and 3\% Laminaria japonica powder contributed to improving the sensory characteristics of reduced-fat pork patties. Additionally, Turhan et al. (2005) suggested that adding 1-2\% hazelnut pellicle fiber is appropriate for manufacturing acceptable low-fat beef burgers. Thus, excessively adding dietary fiber to meat product results in a decline in textural and sensory properties. In our study, chicken patties containing the 3\% BSG dietary fiber extract received the highest scores for color, flavor, tenderness, juiciness, and overall acceptance.

In conclusion, adding 3\% BSG dietary fiber extract improved cooking loss, texture, and sensory properties of chicken patties. The BSG dietary fiber extract-added chicken patties were yellower than that of the control chicken patties and all BSG dietary fiber extract-treated chicken patties had a brownish color, which resulted in highly acceptable appearances. The changes in shape (reduction in diameter) of the chicken patties due to cooking were not affected by adding BSG dietary fiber. Therefore, 3\% BSG dietary fiber extract is a good inexpensive source of dietary fiber for improving quality characteristics of chicken patties.

\section{Acknowledgements}

This research was supported (608001-05-4-SB310) by Rural Development Administration (Republic of Korea). The authors also were partially supported by the Brain Korea 21 (BK 21) Project from Ministry of Education and Human Resources Development (Republic of Korea).

\section{References}

1. Aliyu, S. and Bala, M. (2011) Brewer's spent grain: A review of its potentials and applications. African J. Biotechnol. 10, 324-331.

2. AOAC (2007) Official methods of analysis of AOAC. 18th ed., Association of Official Analytical Chemists, Washington, DC.

3. Bourne, M. C. (1978) Texture profile analysis. Food Technol. 32, 62-66.
4. Choi, Y. S., Choi, J. H., Han, D. J., Kim, H. Y., Kim, H. W., Lee, M. A., Chung, H. J., and Kim, C. J. (2012) Effects of Laminaria japonica on the physico-chemical and sensory characteristics of reduced-fat pork patties. Meat Sci. 91, 1-7.

5. Choi, Y. S., Choi, J. H., Han, D. J., Kim, H. Y., Lee, M. A., Kim, H. W., Jeong, J. Y., and Kim, C. J. (2011) Effects of rice bran fiber on heat-induced gel prepared with pork salt-soluble meat proteins in model system. Meat Sci. 88, 59-66.

6. Choi, Y. S., Choi, J. H., Han, D. J., Kim, H. Y., Lee, M. A., Kim, H. W., Jeong, J. Y., and Kim, C. J. (2009) Characteristics of low-fat meat emulsion system with pork fat replaced by vegetable oils and rice bran fiber. Meat Sci. 82, 266-271.

7. Choi, Y. S., Park, K. S., Kim, H. W., Hwang, K. E., Song, D. H., Choi, M. S., Lee, S. Y., Paik, H. D., and Kim, C. J. (2013) Quality characteristics of reduced-fat frankfurters with pork fat replaced by sunflower seed oils and dietary fiber extracted from makgeolli lees. Meat Sci. 93, 652-658.

8. Farouk, M. M., Wieliczko, K., Lim, R., Turnwald, S., and MacDonald, G. A. (2002) Cooked sausage batter cohesiveness as affected by sarcoplasmic proteins. Meat Sci. 61, 85-90.

9. Feiner, G. (2006) Whole-muscle brine-injected products. In: Meat products handbook. CRC Press, NW, USA, pp. 142158.

10. Fernández-Ginés, J. M., Fernández-López, J., Sayas-Barberá, E., Sendra, E., and Pérez-Álvarez, J. A. (2004) Lemon albedo as a new source of dietary fiber: Application to bologna sausages. Meat Sci. 67, 7-13.

11. García, M. L., Dominguez, R., Galvez, M. D., Casas, C., and Selgas, M. D. (2002) Utilization of cereal and fruit fibres in low fat dry fermented sausages. Meat Sci. 60, 227-236.

12. Gornall, A. G., Bardawill, C. J., and David, M. M. (1949) Determination of serum proteins by means of the Biuret reaction. J. Biol. Chem. 177, 751-766.

13. Gupta, M., Abu-Ghannam, N., and Gallaghar, E. (2010) Barely for brewing: characteristics changes during malting, brewing and application of its by-products. Compr. Rev. Food Sci. F. 9, 318-328.

14. Hughes, E., Cofrades, S., and Troy, D. J. (1997) Effects of fat level, oat fibre and carrageenan on frankfurters formulated with 5, 12 and 30\% fat. Meat Sci. 45, 273-281.

15. Jadhav, S. J., Lutz, S. E., Ghorpade, V. M., and Salukhe, D. K. (1998) Barley: chemistry and value-added processing. Crit. Rev. Food Sci. Nutr. 38, 123-171.

16. McCord, A., Smyth, A. B., and O’Neill, E. E. (1998) Heatinduced gelation properties of salt-soluble muscle proteins as affected by non-meat proteins. J. Food Sci. 63, 580-583.

17. Murphy, R. Y., Johnson, E. R., Duncan, L. K., Clausen, E. C., Davis, M. D., and March, J. A. (2001) Heat transfer properties, moisture loss, product yield, and soluble proteins in chicken breast patties during air convection cooking. Poult. Sci. 80, 508-514.

18. Mussatto, S. I., Dragone, G., and Roberto, I. C. (2006) Brewers' spent grain: generation, characteristics and potential applications. J. Cereal Sci. 43, 1-14.

19. Mussatto, S. I., Dragone, G., and Roberto, I. C. (2008) Hydrogen peroxide bleaching of cellulose pulps obtained 
from brewer's spent grain. Cellulose 15, 641-649.

20. Özvural, E. B., Vural, H., Gökbulut, İ., and Özboy-Özbaş, Ö. (2009) Utilization of brewer's spent grain in the production of Frankfurters. Int. J. Food Sci. Technol. 44, 10931099.

21. Piñero, M. P., Parra, K., Huerta-Leidenz, N., Arenas de Moreno, L., Ferrer, M., Araujo, S., and Barboza, Y. (2008) Effects of oat's fibre ( $\beta$-glucan) as a fat replacer on physical, chemical, microbiological and sensory properties of low-fat beef patties. Meat Sci. 80, 675-680.

22. Robertson, J. A. I., Anson, K. J. A., Treimo, J., Faulds, C. B., Brocklehurst, T. F., Eijsink, V. G. H., and Waldron, K. W. (2010) Profiling brewer's spent grain for composition and microbial ecology at the site of production. LWT-Food Sci. Technol. 43, 890-896.

23. Saffle, R. L. and Galbreath, J. W. (1964) Quantitative determination of salt-soluble protein in various types of meat. Food Technol. 18, 1943-1944.

24. SAS. (2008) SAS/STAT Software for PC. Release 9.2, SAS Institute Inc., Cary, NC, USA.

25. Thebaudin, J. Y., Lefebvre, A. C., Harrington, M., and Bourgeois, C. M. (1997) Dietary fibres: nutritional and technological interest. Trend. Food Sci. Technol. 8, 41-48.
26. Troutt, E., Hunt, M., Johnson, D., Claus, J., Kastener, C., and Kropf, D. (1992) Characteristics of low-fat ground beef containing texture-modifying ingredients. J. Food Sci. 57, 1924.

27. Turhan, S., Sagir, I., and Ustun, N. S. (2005) Utilization of hazelnut pellicle in low-fat beef burgers. Meat Sci. 71, 312316.

28. Waszkowiak, K. and Szymandera-Buszka, K. (2008) The application of wheat fibre and soy isolate impregnated with iodine salts to fortify processed meats. Meat Sci. 80, 13401344.

29. Yilmaz, I. (2004) Effects of rye bran addition on fatty acid composition and quality characteristics of low-fat meatballs. Meat Sci. 67, 245-249.

30. Yllmaz, İ. (2005) Physicochemical and sensory characteristics of low fat meatballs with added wheat bran. J. Food Eng. 69, 369-373.

31. Yılmaz, İ. and Dağlığlu, O. (2003) The effect of replacing fat with oat bran on fatty acid composition and physicochemical properties of meatballs. Meat Sci. 65, 819-823.

(Received 2012.9.25/Revised 2013.1.7/Accepted 2013.1.18) 